\title{
PERAN STRUKTUR MODAL SEBAGAI MEDIATOR ANTARA PERTUMBUHAN PERUSAHAAN DAN NILAI PERUSAHAAAN
}

\author{
I Gusti Putu Ayu Ona Yunita ${ }^{1}$ \\ Luh Gede Sri Artini²
}

\author{
${ }^{1,2}$ Fakultas Ekonomi dan Bisnis Universitas Udayana (Unud), Bali, Indonesia \\ email: onayunita21@gmail.com
}

\begin{abstract}
ABSTRAK
Nilai Perusahaan adalah indikator yang penting dalam menilai kinerja suatu perusahaan. Besar kecilnya suatu nilai perusahaan dapat mempengaruhi investor dalam melakukan investasinya. Tujuan penelitian ini dilakukan untuk mengetahui signifikan pengaruh pertumbuhan perusahaan dan nilai perusahaan, pengaruh struktur modal dan nilai perusahaan, pengaruh pertumbuhan perusahaan dan struktur modal, serta mengetahui pertumbuhan perusahaan dan nilai perusahaan yang di mediasi oleh struktur modal. Penelitian ini dilakukan pada perusahaan industri barang konsumsi yang terdaftar di Bursa Efek Indonesia periode 2014-2016. Jumlah sampel yang digunakan yaitu berjumlah 26 perusahaan dengan menggunakan metode purposive sampling. Penelitian ini menggunakan teknik analisis jalur (path analysis). Berdasarkan analisis yang telah ditemukan bahwa pertumbuhan perusahaan berpengaruh positif dan tidak signifikan terhadap nilai perusahaan, struktur modal berpengaruh positif dan tidak signifikan terhadap nilai perusahaan, pertumbuhan perusahaan berpengaruh positif dan signifikan terhadap struktur modal serta struktur modal mampu memediasi pengaruh pertumbuhan perusahaan terhadap nilai perusahaan.
\end{abstract}

Kata kunci: struktur modal, pertumbuhan perusahaan, nilai perusahaan

\begin{abstract}
Company value is an important indicator in assessing the performance of a company. The size of a company's value can affect investors in making investments. The purpose of this study was to determine the significant influence of company growth and firm value, the influence of capital structure and firm value, the influence of company growth and capital structure, and to know the company's growth and company value mediated by capital structure. This research was conducted on consumer goods industry companies listed on the Indonesia Stock Exchange for the 2014-2016 period. The number of samples used is 26 companies using purposive sampling method. This study uses path analysis techniques (path analysis). Based on the analysis that has been found that the growth of the company has a positive and not significant effect on firm value, capital structure has a positive and not significant effect on firm value, company growth has a positive and significant effect on capital structure and capital structure capable of mediating the influence of company growth on firm value.
\end{abstract}

Keywords: capital structure, company growth, company value 


\section{PENDAHULUAN}

Keadaan perekonomian pada saat ini telah menciptakan persaingan yang tinggi antara perusahaan dalam dunia industri. Adanya persaingan yang tinggi menyebabkan setiap perusahaan dituntut untuk memiliki strategi yang tepat sehingga perusahaan tersebut memiliki keunggulan yang dapat digunakan untuk bersaing dengan perusahaan kompetitornya dan dapat tetap meningkatkan kinerja perusahaan ditengah persaingan yang ada. Manajemen keuangan adalah salah satu faktor yang penting dalam meningkatkan kinerja perusahaan dan mempengaruhi keberhasilan suatu perusahaan. Tujuan akhir dari manajemen keuangan adalah memaksimumkan nilai perusahaan atau memaksimumkan kemakmuran pemegang saham (Wiagustini, 2013:8).

Nilai perusahaan adalah harga yang bersedia dibayar oleh calon pembeli apabila perusahaan dijual (Husnan dan Pudjiastuti, 2012:275). Nilai perusahaan sangat penting karena mencerminkan kinerja perusahaan yang dapat mempengaruhi persepsi investor terhadap perusahaan (Hermuningsih, 2013). Ada beberapa cara yang digunakan untuk mengukur nilai perusahaan yaitu pendekatan nilai sekarang, price earning ratio (PER), price book to value (PBV), rasio harga terhadap aliran kas dan pendekatan economic value added (EVA). Pada penelitian ini nilai perusahaan di ukur menggunakan price to book value (PBV) dikarenakan PBV adalah perbandingan antara harga saham dengan nilai buku per lembar saham dengan artian lain perbandingan dari harga saham dengan ekuitasnya. Semakin tinggi price to book value, maka mencerminkan tingkat kemakmuran yang tinggi pula bagi pemegang saham.

Fenomena nilai perusahaan yang terjadi pada perusahaan industry barang konsumsi, di mana dalam menjalankan operasi bisnisnya tentu saja perusahaan dihadapkan pada situasi dimana nilai perusahaan akan mengalami peningkatan atau bahkan mengalami penurunan. Seperti terjadi pada 10 Januari 2019 dimana sektor barang konsumsi pada perdagangan saat ini berhasil peningkatan hingga 1,96\% setelah dua hari berturut turut mengalami koreksi yang cukup dalam. Investor merespon positif hasil laporan survei penjualan eceran oleh Bank Indonesia (BI) yang menunjukkan bahwa penjualan eceran pada 2018 lebih baik dibandingkan 2017. Sehingga, saham-saham di sektor barang konsumsi dan manufaktur laris manis hari ini. Perusahaan barang konsumsi yang berkontribusi dalam kinerja IHSG yaitu saham barang konsumsi dari, PT Unilever Indonesia Tbk. (UNVR) melesat Rp 2.325 (5,20\%) menjadi Rp 48.325 per saham. Lainnya, emiten pendatang baru, PT Pollux Investasi International Tbk. (POLI) melesat Rp 815 (49,85\%) di hari perdananya menjadi Rp 2.450 per saham.

Fenomena lainnya yang menyatakan penurunan nilai saham industry barang konsumsi pada tanggal 29 April 2018, sejak akhir tahun 2017 lalu, PT HM Sampoerna Tbk (HMSP) masih memimpin sebagai perusahaan dengan kapitalisasi pasar terbesar. Kala itu, nilai HMSP setara dengan Rp 550,18 triliun. Namun, kemarin nilai market cap HMSP hanya Rp 425 triliun. Angka ini turun 22,75\% dibandingkan posisi akhir tahun 2017 lalu. HMSP pun menempati posisi kedua dari jajaran top market cap. Kini, posisi pertama ditempati oleh PT Bank Central Asia

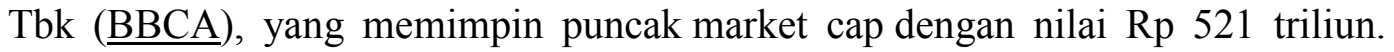
Selain HMSP, nilai market cap emiten konsumer lainnya, seperti PT Unilever 
Indonesia Tbk ( $\underline{\mathrm{UNVR}})$ dan PT Gudang Garam Tbk ( $\underline{\text { GGRM}})$, juga turun cukup dalam.

Pertumbuhan perusahaan ialah salah satu variabel berpengaruh terhadap nilai perusahaan (Sartono, 2014:371). Pertumbuhan perusahaan pada penelitian ini dihitung dengan memakai pertumbuhan total aktiva. Total Asset Growth (TAG) adalah perbedaan total aktiva yang dipunyai oleh perusahaan dari periode sekarang dengan periode sebelumnya pada total aktiva periode sebelumnya (Dewi dan Sudiartha, 2017). Pertumbuhan aset bisa memberikan pengaruh ke nilai perusahaan. Pertumbuhan aset sangat dinantikan untuk kemajuan perusahaan secara internal dan eksternal perusahaan, karena pertumbuhan yang tinggi akan membantu perkembangan perusahaan (Dewi dan Sudiartha, 2017). Pertumbuhan aset menunjukkan besarnya dana yang dialokasikan oleh perusahaan ke dalam asetnya. Pertumbuhan aset akan menuntut perusahaan untuk menyediakan dana yang memadai. Pertumbuhan aset yang meningkat memberikan sinyal bahwa perusahaan mampu menggunakan asetnya secara optimal, hal ini menyebabkan investor akan tertarik untuk melakukan investasi sehingga permintaan saham perusahaan meningkat dan pada akhirnya nilai perusahaan juga meningkat (Susanto, 2016).

Hasil penelitian terdahulu menggambarkan hubungan yang bertentangan antara pertumbuhan perusahaan dengan nilai perusahaan (Hermuningsih, 2013), (Dewi dan Sudiartha, 2017), (Sari dan Abundanti, 2014) menyatakan hasil bahwa pertumbuhan perusahaan memiliki pengaruh positif dan signifikan terhadap nilai perusahaan ketika pertumbuhan perusahaan menjadi indikator dari nilai perusahaan dilihat dari sudut pandang investor, ketika pertumbuhan perusahaan menunjukkan perkembangan yang baik dimana pertumbuhan suatu perusahaan tersebut dapat memberikan keuntungan dan perusahaan mengharapkan rate of return dari investasi yang dilakukan. Hal ini berarti pertumbuhan perusahaan menunjukkan pengaruh yang positif terhadap nilai perusahaaan, dimana semakin baik pertumbuhan perusahaan dapat meningkatkan nilai perusahaan.

Penelitian lainnya dari (Chen dan Chen, 2011) yang menjelaskan bahwa pertumbuhan perusahaan berpengaruh negatif dan signifikan terhadap nilai perusahaan hal ini disebabkan karena setiap penurunan perubahan total aktiva perperiode penelitian maka hal tersebut tidak akan meberikan pengaruh pada harga perlembar saham terhadap ekuitas perlembar saham dikalangan investor.

Hasil penelitian lainnya dari (Sudiani dan Darmayanti, 2016), (Riaz dan Qasim, 2016), dan (Dewi dan Sudiartha, 2017) menggambarkan bahwa pertumbuhan perusahaan berpengaruh positif dan tidak signifikan terhadap Nilai Perusahaan. Tidak signifikan itu menegaskan bahwa seumpama pertumbuhan perusahaan ketika timbul peningkatan hingga tidak akan dibarengi oleh peningkatan nilai perusahaan. Peristiwa ini lantaran pertumbuhan yang tinggi menyebabkan kebutuhan budget meningkat. Bertambah besar tingkat pertumbuhan perusahaan, hingga kian tinggi biaya yang diwajibkan dalam mengelola kegiatan produksi perusahaan. Perusahaan hendak memfokuskan biaya untuk kepentingan pertumbuhan perusahaan dipadankan dengan kesejahteraan shareholder. Hal ini akan memicu penanam modal tidak percaya pada perusahaan dan nilai perusahaan akan menyebabkan kemerosotan (Meidiawati dan Mildawati, 2016). 
Menurut (Sartono, 2014:248) pertumbuhan perusahaan ialah salah satu faktor penting yang dipikirkan untuk menghitung nilai struktur modal perusahaan. (Brigham \& Houston, 2011:189) mengatakan bahwa di dalam teori pecking order diujarkan bahwa perusahaan lebih menjurus memprioritaskan dana dari dalam, lantaran tidak mencukupi, lalu tunggakan merupakan opsi pertama. Perusahaan melalui tingkat pertumbuhan aset yang cepat wajib lebih besar mengandalkan dana eksternal. Semakin tinggi pertumbuhan perusahaan maka semakin besar kebutuhan dana untuk pembiayaan ekspansi. Perusahaan-perusahaan yang memiliki pertumbuhan yang cepat seringkali harus meningkatkan aktiva tetapnya. Perusahaan-perusahaan melalui tingkat pertumbuhan yang tinggi lebih mengutamakan memakai hutang dipadankan dengan perusahaan yang mempunyai pertumbuhan lebih lambat (Hermuningsih, 2013).

Hasil penelitian sebelumnya tentang pengaruh pertumbuhan perusahaan terhadap struktur modal yang menyatakan hasil penelitian (Dwilestari, 2010) menyatakan Tingkat pertumbuhan perusahaan menunjukkan seberapa besar perusahaan dalam menggunakan hutang sebagai sumber pembiayaan. Perusahaan yang memiliki tingkat pertumbuhan yang tinggi akan cenderung menghasilkan arus kas yang lebih besar sehingga perusahaan akan lebih mengandalkan pendanaan internal. Dalam hubungannya dengan struktur modal, perusahaan dengan tingkat pertumbuhan yang tinggi sebaiknya menggunakan ekuitas sebagai sumber pembiayaannya agar tidak terjadi keagenan antara pemegang saham dengan manajemen perusahaan. Sebaliknya, perusahaan dengan tingkat pertumbuhan yang rendah lebih baik menggunakan hutang sebagai sumber pembiayaannya karena pembayaran hutang akan mengharuskan perusahaan tersebut membayar bunga secara teratur.

Hasil penelitian (Kartika, 2016) menyatakan bahwa pertumbuhan perusahaan memiliki pengaruh negatif terhadap stuktur modal dimana pada tingkat pertumbuhan perusahaan menunjukkan seberapa besar penggunaan hutang sebagai sumber pembiayaannya, perusahaan dengan tingkat pertumbuhan yang tinggi cenderung menghasilkan arus kas yang lebih besar sehingga perusahaan tersebut akan mengandalkan pembiayaan internalnya dimana dana ini diperoleh dari kegiatan operasional perusahaan.

Pada penelitian lain hubungan antara pertumbuhan perusahaan terhadap struktur modal, hasil observasi dari (Purwohandoko, 2017), (Akinyomi dan Olagunju, 2013), (Hermuningsih, 2013) menunjukkan hasil bahwa pertumbuhan perusahaan berpengaruh positif terhadap struktur modal, hal ini karena pertumbuhan perusahaan yang lebih tinggi, maka untuk penggunaan hutang perusahaan akan semakin rendah menggunakannya.

Nilai Perusahaan menggambarkan bahwa nilai perusahaan itu menjadi salah satu pengaruh pada struktur modal. (Sartono, 2014;225) struktur modal adalah perbandingan jumlah short term debt yang bersifat konstan, long term debt, preferred stock dan common stock. Struktur modal adalah persoalan yang berarti bagi perusahaan karena baik buruknya struktur modal akan memberikan efek spontan pada keadaan keuangan perusahaan yang akhir nya akan berpengaruh pada nilai perusahaan (Susanto, 2016). Apabila struktur modal tidak merubah nilai perusahaan, berarti tidak ada struktur modal yang terbaik. Jika dengan merubah 
struktur modal ternyata nilai perusahaan berubah, maka akan diperoleh struktur modal yang terbaik. Menurut (Husnan dan Pudjiastuti, 2012:263) struktur modal yang dapat memaksimumkan nilai perusahaan, atau harga saham adalah struktur modal yang terbaik. Struktur modal dalam penelitian ini diukur menggunakan Debt to Equity Ratio (DER) yaitu perbandingan antara total utang dengan total modal sendiri (Sartono, 2014:121). Alasan penelitian ini menggunakan struktur modal sebagai mediasi untuk mengetahui pengaruh pertumbuhan perusahaan terhadap nilai perusahaan, karena perusahaan yang memiliki struktur modal yang lebih besar dibandingkan hutang akan lebih mudah untuk mengembangkan perusahaan dan meningkatkan profit perusahaan sehingga meningkatkan persepsi investor terhadap perusahaan. Peningkatan persepsi investor terhadap perusahaan juga akan membuat pertumbuhan perusahaan meningkat, pembayaran dividen kepada investor juga meningkat yang kemudian akan memberikan dampak positif terhadap nilai perusahaan (Parta dan Sedana, 2018).

Hasil penelitian terdahulu yang di lakukan oleh (Susanto, 2016), dan (Fau, 2015) menyatakan hasil bahwa struktur modal memiliki pengaruh negatif dan signifikan terhadap nilai perusahaan. Hasil penelitian lainnya dari (Parta dan Sedana, 2018), (Hermuningsih, 2013), (Hoque et al., 2014), (Dewi dan Sudiartha, 2017), dan (Meidiawati \& Mildawati, 2016) menggambarkan bahwa struktur modal menyampaikan pengaruh yang positif dan signifikan pada nilai perusahaan, perusahaan amat dianjurkan bakal terus-menerus menyamakan profit marjinal menggunakan pinjaman jangka panjang dengan anggaran marjinal pinjaman jangka panjang sebelum menyimpulakn penggunaanya untuk membiayai operasi suatu perusahaan. Hal ini disebabkan karena hutang jangka panjang berdampak positif terhadap nilai perusahaan seperti hal nya modal ekuitas.

Penelitian ini dilakukan pada perusahaan sub sektor industry barang konsumsi yang terdaftar di Bursa Efek Indonesia (BEI). Sub sektor industri barang konsumsi yang digunakan sebagai sampel pada penelitian ini yaitu berjumlah 26 perusahaan yang terdaftar di Bursa Efek Indonesia tahun 2014-2016. Pada grafik 1.1 dapat dilihat perkembangan nilai perusahaan yang diukur dengan price to book value (PBV) yang mengalami fluktuasi.

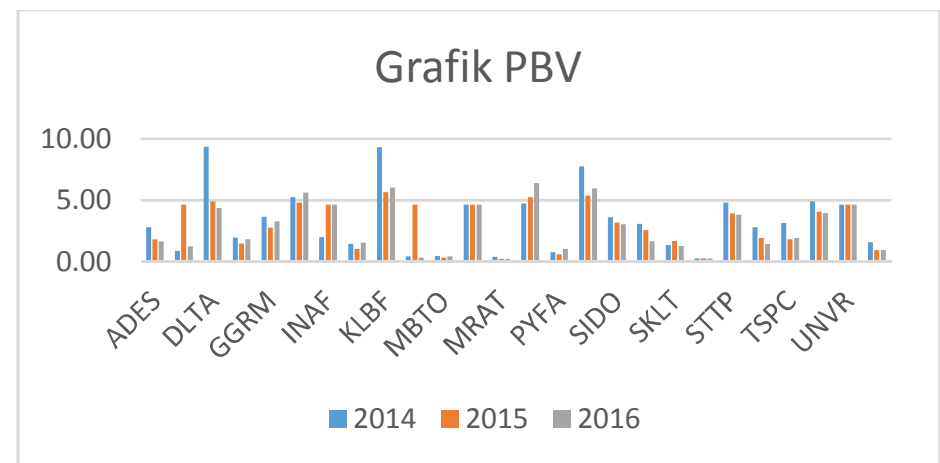

Gambar 1. Perkembangan PBV perusahaan industri barang konsumsi pada periode $2014-2016$.

Sumber: www.idx.co.id, 2018 
Gambar 1. menunjukkan hasil nilai perusahaan yang diolah dengan menggunakan proksi PBV pada perusahaan industry barang konsumsi tahun 20142016 yang mengalami fluktuasi. Berdasarkan gambar 1. nilai PBV terendah diperoleh oleh Mustika Ratu Tbk. pada tahun 2015-2016 sedangkan perusahaan dengan nilai PBV tertinggi dimiliki Delta Djakarta Tbk. pada tahun 2014. Bila ketidakstabilan nilai perusahaan tidak diperbaiki, maka akan menurunkan kredibilitas perusahaan di mata investor.

Penelitian dari (Dewi dan Sudiartha, 2017) menyatakan pertumbuhan total aktiva yang tinggi maka akan lebih mudah untuk mendapatkan perhatian dari pihak investor dan kreditor karena dapat mencerminkan perusahaan tersebut mampu untuk menghasilkan laba yang di manfaatkan untuk menambah jumlah aktiva yang kemudian dapat digunakan untuk meningkatkan nilai perusahaan.

Hasil penelitian yang dilakukan oleh (Dhani dan Utama, 2017), dan (Hermuningsih, 2013), menyatakan bahwa pertumbuhan perusahaan berpegaruh positif dan signifikan terhadap nilai perusahaan.

Berdasarkan hasil penelitian tersebut maka disimpulkan hipotesis untuk pengaruh pertumbuhan perusahaan terhadap nilai perusahaan adalah sebagai berikut:

$\mathrm{H}_{1}$ : Pertumbuhan Perusahaan berpengaruh positif dan signifikan terhadap Nilai

Perusahaan.

Perusahaan sangat disarankan untuk selalu membandingkan keuntungan marjinal dengan menggunakan hutang jangka panjang dengan biaya marjinal hutang jangka panjang sebelum menyimpulakn penggunaanya untuk membiayai operasi suatu perusahaan. Hal ini disebabkan karena hutang jangka panjang berdampak positif terhadap nilai perusahaan seperti hal nya modal ekuitas (Antwi et al., 2012). Pendekatan Modligani dan Miller ada pajak, memprediksi hubungan positif antara struktur modal dengan nilai perusahaan, perusahaan yang memiliki hutang akan membayar bunga, sehingga akan membayar pajak penghasilan yang lebih kecil dan meningkatkan nilai perusahaan (Husnan dan Pudjiastuti, 2012:169).

Hasil penelitian yang dilakukan oleh (Parta dan Sedana, 2018), (Hermuningsih, 2013), (Hoque et al., 2014), (Rehman, 2016), (Dewi dan Sudiartha, 2017), (Meidiawati dan Mildawati, 2016), menyatakan hasil bahwa struktur modal memiliki pengaruh positif terhadap nilai perusahaan.

Berdasarkan hasil penelitian tersebut maka disimpulkan hipotesis untuk pengaruh struktur modal terhadap nilai perusahaan adalah sebagai berikut :

$\mathrm{H}_{2}$ : Struktur Modal berpengaruh positif dan signifikan terhadap Nilai Perusahaan.

Perusahaan dengan tingkat pertumbuhan aset yang tinggi harus lebih banyak mengandalkan dana eksternal. Semakin tinggi pertumbuhan perusahaan maka semakin besar kebutuhan dana untuk pembiayaan ekspansi. Perusahaan-perusahaan yang memiliki tingksat pertumbuhan yang tinggi cenderung lebih banyak menggunakan hutang dibandingkan dengan perusahaan dengan pertumbuhan lebih lambat (Hermuningsih, 2013). 
Hasil penelitian yang dilakukan oleh (Dewi dan Sudiartha, 2017), (Akinyomi dan Olagunju, 2013), dan (Daskalakis et al., 2014), menyatakan hasil bahwa pertumbuhan perusahaan memiliki pengaruh positif terhadap struktur modal.

Berdasarkan hasil penelitian tersebut maka disimpulkan hipotesis untuk pengaruh pertumbuhan perusahaan terhadap struktur modal adalah sebagai berikut: $\mathrm{H}_{3}$ : Pertumbuhan perusahaan berpengaruh secara positif dan signifikan

Pertumbuhan perusahaan dinyatakan dengan perubahan (peningkatan atau penurunan) total aset masa ini dibandingkan dengan total aset masa lalu, perusahaan mengharapkan adanya pertumbuhan perusahaan karena baiknya pertumbuhan perusahaan maka akan memberikan dampak baik terhadap perkembangan perusahaan. Cepatnya suatu pertumbuhan perusahaan akan memerlukan pendanaan berupa modal dimana struktur modal sangat berperan penting dalam pertumbuhan perusahaan. Modal berperan penting dalam pertumbuhan perusahaan karena apabila perusahaan menggunakan modal sebaik-baiknya maka akan meningkatkan nilai dari perusahaan tersebut. Teori trade off menyatakan bahwa apabila posisi struktur modal berada dibawah titik optimal maka setiap penambahan hutang akan meningkatkan nilai perusahaan. Sebaliknya, apabila posisi struktur modal berada diatas titik optimal maka setiap penambahan hutang akan menurunkan nilai perusahaan (Parta dan Sedana, 2018). Dari teori trade off tersebut dapat disimpulkan ketika petumbuhan perusahaan mengalami peningkatan yang disebabkan oleh optimalnya posisi struktur modal maka secara tidak langsung akan meningkatkan nilai perusahaan.

$\mathrm{H}_{4}$ : Struktur modal mampu memediasi pengaruh pertumbuhan perusahaan terhadap nilai perusahaan

\section{METODE PENELITIAN}

Penelitian ini dilakukan pada perusahaan Industri Barang Konsumsi yang terdaftar di Bursa Efek Indonesia melalui situs www.idx.co.id. Objek pada penelitian ini adalah variabel nilai perusahaan, struktur modal dan pertumbuhan perusahaan.

Nilai perusahaan diukur dengan Price Book Value (PBV) yaitu perbandingan antara harga pasar per saham dengan nilai buku pada Perusahaan Industri Barang Konsumsi di Bursa Efek Indonesia Periode 2014-2016. Hasil dari perhitungan Price Book Value (PBV) dalam bentuk \% (persentase).

$\mathrm{PBV}=\frac{\text { Harga pasar per lembar saham }}{\text { Nilai buku }} \times 100$

Pertumbuhan Perusahaan diukur dengan menggunakan pertumbuhan total aktiva. Total Asset Growth (TAG) adalah selisih total aktiva yang dimiliki oleh perusahaan pada periode sekarang dengan periode sebelumnya terhadap total aktiva periode sebelumnya pada Perusahaan Industri Barang Konsumsi di Bursa Efek Indonesia Periode 2014-2016. Hasil dari perhitungan Total Asset Growth (TAG) dalam bentuk \% (persentase).

$\mathrm{TAG}=\frac{\text { Total aset tahun sekarang-Total aset } 1 \text { tahun sebelumnya }}{\text { Total aset } 1 \text { tahun sebelumnya }} \times 100 \%$

Struktur modal diukur dengan Debt to Equity Ratio (DER) yaitu perbandingan antara total utang dengan total modal sendiri pada Perusahaan Industri Barang Konsumsi di Bursa Efek Indonesia Periode 2014-2016. Hasil dari perhitungan Debt to Equity Ratio (DER) dalam bentuk \% (persentase). 
$\mathrm{DER}=\frac{\text { Total utang }}{\text { Total modal sendiri }} \times 100 \%$

Populasi dalam penelitian ini adalah seluruh perusahaan industri barang konsumsi di Bursa Efek Indonesia periode 2014-2016 yang berjumlah 40 perusahaan. Sampel yang digunakan yaitu metode purposive sampling dalam penentuan sampelnya.

Proses pemilihan sampel perusahaan, perusahaan industri barang konsumsi yang terdaftar di BEI berjumlah 40 perusahaan periode tahun 2014-2016. Populasi tersebut diseleksi kembali berdasarkan metode purposive sampling dengan kriteria yang ditentukan sehingga diperoleh sampel. Perusahaan yang tidak digunakan sebagai sampel sebanyak 2 perusahaan dikarenakan Chitose Internasional Tbk yang baru terdaftar pada tanggal 27 juni 2014 dan tidak terdapat laporan keuangan pada tahun 2014. Kino Indonesia Tbk yang baru terdaftar pada tanggal 11 Desember 2015 dan tidak terdapat laporang keuangan pada tahun 2015 dan 2015. Jumlah data yang digunakan pada penelitian ini sebanyak 26 data perusahaan, terdapat data yang mengalami outlier sebanyak 12 data perusahaan sehingga jumlah data perusahaan yang sebelumnya berjumlah 38 data perusahaan menjadi 26 data perusahaan.

Dalam penelitian ini teknik yang digunakan untuk mengetahui pengaruh pertumbuhan perusahaan terhadap nilai perusahaan yang di mediasi oleh struktur modal adalah teknik path analysis. Sebelum melakukan analisis jalur, peneliti terlebih dahulu akan melakukan uji asumsi klasik yaitu uji normalitas, multikolinearitas, heteroskedastisitas dan autokorelasi yang bertujuan untuk mendapat nilai parameter penduga yang sah. Nilai yang sah akan didapat apabila uji asumsi klasik memenuhi asumsi normalitas, dan pada multikolinearitas, heterokedasitas dan autokorelasi tidak terjadi.

Analisis statistik deskriptif merupakan deskripsi data dari seluruh variabel yang diteliti. Hasil dari analisis statistik deskriptif memperlihatkan jumlah data yang digunakan dalam penelitian, nilai minimum, nilai maksimum, mean (ratarata), dan deviasi standar. Penelitian ini menggunakan variabel pertumbuhan perusahaan (TAG), nilai perusahaan (PBV), dan struktur modal (DER).

Tabel 1.

Hasil Analisis Statistik Deskriptif

\begin{tabular}{cccccc}
\hline & N & Minimum & Maximum & Mean & Std. Deviation \\
\hline N Valid & 78 & & & & \\
TAG (\%) & 78 & $-7,40$ & 30,52 & 8,6472 & 8,12494 \\
DER (\%) & 78 & $-5,41$ & 37,68 & 13,8644 & 8,81166 \\
PBV (\%) & 78 &, 24 & 9,33 & 3.0278 & 2,14706 \\
\hline
\end{tabular}

Sumber: Data diolah, 2018

Berdasarkan Tabel 1. menunjukkan bahwa jumlah data yang digunakan dalam penelitian ini berjumlah 78 data yang didapatkan dari 26 data laporan keuangan perusahaan dikalikan 3 tahun (2014-2016).

Variabel Pertumbuhan Perusahaan (TAG) memiliki nilai rata-rata sebesar $8,6472 \%$ dan memiliki standar deviasi sebesar 8,12494\%. Nilai minimum sebesar $-7,40 \%$ dimiliki oleh Pyridam Farma Tbk. pada tahun 2015 sedangkan nilai maksimum sebesar 30,52\% dimiliki oleh Sekar Bumi Tbk. pada tahun 2014. 
Variabel Struktur Modal (DER) memiliki nilai rata-rata sebesar 13,8644\% dan memiliki standar deviasi sebesar 8,81166\%. Nilai minimum sebesar $-5,41 \%$ dimiliki oleh Indofarma (Persero) Tbk. pada tahun 2016 sedangkan nilai maksimum sebesar 37,68\% dimiliki oleh Delta Djakarta Tbk. pada tahun 2014.

Variabel Nilai Perusahaan (PBV) memiliki nilai rata-rata sebesar 3,0278\% dan memiliki standar deviasi sebesar 2,14706 \%. Nilai minimum sebesar 24\% dimiliki oleh Mustika Ratu Tbk. pada tahun 2015 dan pada tahun 2016 sedangkan nilai maksimum sebesar 9,33\% dimiliki oleh Delta Djakarta Tbk. pada tahun 2014.

Uji asumsi klasik digunakan untuk mengetahui kelayakan data yang diuji sudah memenuhi persyaratan atau tidak, sehingga tidak menghasilkan penafsiran yang bias dalam pengujian. Analisis jalur (path analysis) menggunakan dua tahap uji asumsi klasik. Model pertama pada $\left(\mathrm{Y}_{1}\right)$ untuk menguji variabel eksogen Pertumbuhan Perusahaan (TAG) terhadap variabel endogen Struktur Modal (DER). Model kedua pada $\left(\mathrm{Y}_{2}\right)$ untuk menguji variabel eksogen Pertumbuhan Perusahaan (TAG) dan Struktur Modal (DER) terhadap variabel endogen Nilai Perusahaan (PBV). Uji asumsi klasik terdiri dari uji normalitas, uji multikolinearitas, uji heteroskedastisitas, dan uji autokorelasi akan dijelaskan sebagai berikut :

Uji normalitas bertujuan untuk menguji apakah dalam residual dari model regresi yang dibuat berdistribusi normal ataukah tidak. Data itu akan berdistribusi normal bila tingkat signifikan lebih besar dari pada alpha atau taraf signifikansi yang ditetapkan yaitu 0,05. Tingkat signifikansi pada hasil output SPSS dapat dilihat pada Asymp. Sig. (2-tailed).

Tabel 2.

Uji Normalitas Model Pertama

\begin{tabular}{ccc}
\hline & & Unstandarzed Residual \\
\hline N & & 78 \\
Normal Parameters ${ }^{\mathrm{a}, \mathrm{b}}$ & Mean &, 0000000 \\
& Std. Deviation & 8,17544590 \\
Most Extreme & Absolute &, 073 \\
Differences & Positive &, 068 \\
& Negative &,- 073 \\
Kolmogorov-Smirnov Z & Mean &, 643 \\
Asymp. Sig. (2-tailed) & &, 083 \\
\hline
\end{tabular}

Sumber: Data diolah, 2018

Pada Tabel 2. menunjukkan hasil output SPSS model pertama, dimana Asymp. Sig. (2-tailed) menunjukkan angka sebesar 0,803>0,05, menunjukkan bahwa data berdistribusi normal dan model pertama dinyatakan memenuhi uji normalitas.

Tabel 3.

Uji Normalitas Model Kedua

\begin{tabular}{|c|c|c|}
\hline & & Unstandardized Residual \\
\hline $\mathrm{N}$ & & 78 \\
\hline Normal Parameters ${ }^{\mathrm{a}, \mathrm{b}}$ & Mean &, 0000000 \\
\hline & Std. Deviation & 1,80185292 \\
\hline Most Extreme & Absolute &, 121 \\
\hline
\end{tabular}

Bersambung.. 
Lanjutan Tabel 3.

\begin{tabular}{ccc}
\hline & & UnstandardizedResidual \\
\hline Differences & Positive &, 121 \\
Negative &,- 104 & Negative \\
Kolmogorov-Smirnov Z & 1.066 \\
Asymp. Sig (2-tailed) &, 206 \\
\hline
\end{tabular}

Sumber: Data diolah, 2018

Pada Tabel 3. menunjukkan hasil output SPSS model kedua, dimana Asymp. Sig. (2-tailed) menunjukkan angka sebesar 0,206 >0,05, menunjukkan bahwa data berdistribusi normal dan model kedua dinyatakan memenuhi uji normalitas.

Uji multikolinearitas memiliki tujuan untuk menguji apakah pada model regresi ditemukan adanya korelasi antar variabel bebas. Jika nilai tolerance lebih dari 10\% atau Variance Inflation Factor (VIF) kurang dari 10, maka dikatakan tidak ada multikolinearitas.

Tabel 4.

Uji Multikolinearitas Model Pertama

\begin{tabular}{lccc}
\hline Model & \multicolumn{2}{c}{ Collinearity Statistics } \\
\hline & TAG $(\%)$ & Tolerance & VIF \\
1 & \multicolumn{2}{c}{1,000} & 1,000 \\
\hline Sumber: Data diolah, 2018 &
\end{tabular}

Sumber: Data diolah, 2018

Pada Tabel 4. menunjukkan hasil output SPSS model pertama, pada variabel pertumbuhan perusahaan (TAG) memiliki nilai tolerance sebesar 1,000 yang lebih kecil dari $10 \%(0,10)$. Sedangkan pada varibel pertumbuhan perusahaan (TAG) memiliki VIF sebesar 1,000 dan variabel pertumbuhan perusahaan (TAG) memiliki VIF sebesar 1,000 yang lebih kecil dari 10, maka dari itu dapat disimpulkan bahwa model pertama tidak ada multikolinearitas.

Tabel 5.

Uji Multikolinearitas Model Kedua

\begin{tabular}{lccc}
\hline Model & & \multicolumn{2}{c}{ Collinearity Statistics } \\
\hline & & Tolerance & VIF \\
1 & TAG (\%) &, 861 & 1,162 \\
& DER (\%) &, 861 & 1,162 \\
\hline
\end{tabular}

Sumber: Data diolah, 2018

Pada Tabel 5. menunjukkan hasil output SPSS model kedua, pada variabel pertumbuhan perusahaan (TAG) memiliki nilai tolerance sebesar 0,861 dan variabel struktur modal (DER) memiliki nilai tolerance sebesar 0,861 yang lebih besar dari $10 \%(0,10)$. Sedangkan pada varibel pertumbuhan perusahaan (TAG) memiliki VIF sebesar 1,162 dan variabel struktur modal (DER) memiliki VIF sebesar 1,162 yang lebih kecil dari 10, maka dari itu dapat disimpulkan bahwa model kedua tidak ada multikolinearitas.

Uji heteroskedastisitas memiliki tujuan untuk menguji apakah dalam model regresi terjadi ketidaksamaan varians dari residual pengamatan satu ke pengamatan yang lainnya. Uji Glejser dilakukan dengan cara meregresi nilai absolute residual 
dari model yang diestimasi terhadap variabel independen. Jika tidak ada satupun variabel bebas yang berpengaruh signifikan terhadap nilai absolute residual atau nilai signifikansinya di atas 5\% maka tidak terjadi heteroskedastisitas.

Tabel 6.

Uji Heteroskedastisitas Model Pertama

\begin{tabular}{|c|c|c|c|c|c|}
\hline \multirow[b]{2}{*}{ Model } & \multicolumn{2}{|c|}{$\begin{array}{c}\text { Unstandardized } \\
\text { Coefficients }\end{array}$} & \multirow{2}{*}{$\begin{array}{c}\text { Standarized } \\
\text { Coefficients } \\
\text { Beta } \\
\end{array}$} & \multirow[b]{2}{*}{$\mathbf{t}$} & \multirow[b]{2}{*}{ Sig. } \\
\hline & B & Std. Error & & & \\
\hline 1 (Constant) & 6,757 &, 767 & & 8,806 &, 000 \\
\hline TAG &,- 004 &, 065 &,- 008 &,- 068 & ,946 \\
\hline
\end{tabular}

Sumber: Data diolah, 2018

Pada Tabel 6. menunjukkan hasil output SPSS model pertama, dimana nilai signifikansi dari variabel pertumbuhan perusahaan (TAG) sebesar 0,946 yang menunjukkan angka lebih besar dari 5\% (0,05), maka dari itu dapat disimpulkan bahwa model pertama tidak terjadi heteroskedastisitas.

Tabel 7.

Uji Heteroskedastisitas Model Kedua

\begin{tabular}{|c|c|c|c|c|c|}
\hline \multirow[b]{2}{*}{ Model } & \multicolumn{2}{|c|}{$\begin{array}{c}\text { Unstandardized } \\
\text { Coefficients }\end{array}$} & \multirow{2}{*}{$\begin{array}{c}\text { Standarized } \\
\text { Coefficients } \\
\text { Beta } \\
\end{array}$} & \multirow[b]{2}{*}{$\mathbf{t}$} & \multirow[b]{2}{*}{ Sig. } \\
\hline & B & Std. Error & & & \\
\hline 1 (Constant) & ,979 & ,257 & & 3,808 & ,000 \\
\hline TAG &, 002 &, 018 &, 014 &, 115 & 908 \\
\hline DER &, 026 &, 016 & ,194 & 1,594 & , 115 \\
\hline
\end{tabular}

Sumber: Data diolah, 2018

Pada Tabel 7. menunjukkan hasil output SPSS model kedua, dimana nilai signifikansi dari variabel pertumbuhan perusahaan (TAG) sebesar 0,908, dan variabel struktur modal (DER) sebesar 0,115 yang menunjukkan angka lebih besar dari 5\% $(0,05)$, maka dari itu dapat disimpulkan bahwa model kedua tidak terjadi heteroskedastisitas.

Uji autokorelasi bertujuan untuk melacak adanya korelasi auto atau pengaruh data dari pengamatan sebelumnya dalam suatu model regresi. Uji autokorelasi dapat dilakukan dengan menggunakan Uji Durbin-Watson (DW-test).

Tabel 8.

Uji Autokorelasi Model Pertama

\begin{tabular}{lccccc}
\hline Model & R & R Square & $\begin{array}{c}\text { Adjusted R } \\
\text { Square }\end{array}$ & $\begin{array}{c}\text { Std. Error of } \\
\text { the Estimate }\end{array}$ & $\begin{array}{c}\text { Durbin- } \\
\text { Watson }\end{array}$ \\
\hline 1 &, $373^{\text {a }}$ &, 139 &, 128 & 8,22906 & 1,793 \\
\hline Sumber: & & & & &
\end{tabular}

Pada Tabel 8. menunjukkan hasil output SPSS model pertama, dimana nilai Durbin-Watson-nya sebesar 1,793. Berdasarkan nilai signifikansi 5\% $(0,05)$, untuk jumlah data sebanyak 78 dan jumlah variabel eksogen $(k=1)$, maka $d_{L}=1,63$ dan $\mathrm{d}_{\mathrm{u}}=1,81$. Nilai Durbin-Watson model pertama sebesar 1,793 lebih besar dari nilai 
$\mathrm{d}_{\mathrm{u}}=1,81$ dan lebih kecil dari nilai $4-\mathrm{d}_{\mathrm{u}}=2,19$ sehingga dapat disimpulkan tidak ada autokorelasi.

Tabel 9.

Uji Autokorelasi Model Kedua

\begin{tabular}{cccccc}
\hline Model & $\mathbf{R}$ & R Square & $\begin{array}{c}\text { Adjusted R } \\
\text { Square }\end{array}$ & $\begin{array}{c}\text { Std. Error of } \\
\text { the Estimate }\end{array}$ & $\begin{array}{c}\text { Durbin- } \\
\text { Watson }\end{array}$ \\
\hline 1 &, $544^{\mathrm{a}}$ &, 296 &, 277 & 1,82572 & 2,211 \\
\hline
\end{tabular}

Sumber: Data diolah, 2018

Pada Tabel 9. menunjukkan hasil output SPSS model kedua, dimana nilai Durbin-Watson-nya sebesar 2,211. Berdasarkan nilai signifikansi 5\% $(0,05)$, untuk jumlah data sebanyak 78 dan jumlah variabel eksogen $(k=2)$, maka $d_{L}=1,01$ dan $d_{u}$ $=1,51$. Nilai Durbin-Watson model kedua sebesar 2,211 lebih besar dari nilai $d_{u}=$ 1,51 dan lebih kecil dari nilai 4- $\mathrm{d}_{\mathrm{u}}=2,49$,sehingga dapat disimpulkan tidak ada autokorelasi.

Analisis Jalur atau path analysis digunakan untuk menganalisis hubungan antar variabel bebas (eksogen) dengan variabel terikat (endogen) dengan tujuan untuk mengetahui pengaruh langsung atau tidak langsungnya. Variabel eksogen dalam penelitian ini adalah Pertumbuhan Perusahaan (TAG), dengan Struktur Modal (DER) sebagai variabel intervening terhadap Nilai Perusahaan (PBV) yang merupakan variabel endogen. Penyelesaian analisis jalur atau path analysis dibagi menjadi dua model yaitu model pertama pengaruh Pertumbuhan Perusahaan (TAG) terhadap Struktur Modal (DER). Model kedua yaitu pengaruh Pertumbuhan Perusahaan (TAG), Struktur Modal (DER) terhadap Nilai Perusahaan (PBV). Langkah-lagkah menguji path analysis adalah sebagai berikut :

Struktur 1 Pertumbuhan Perusahaan terhadap Struktur Modal :

$$
\begin{aligned}
\mathrm{Y}_{1} & =\mathrm{a}+\rho \mathrm{X}_{1}+\mathrm{e}_{1} \ldots \ldots \ldots \ldots \ldots . \\
\mathrm{Y}_{1} & =10,366+0,373+0,139 \mathrm{e}_{1} \\
\mathrm{e}_{1} & =\sqrt{1-R^{2}} \ldots \ldots \ldots \ldots \ldots \ldots \ldots \ldots \\
& =\sqrt{1-0,139}=0,927
\end{aligned}
$$

Struktur 2 Pengaruh Pertumbuhan Perusahaan, Struktur Modal terhadap Nilai perusahaan:

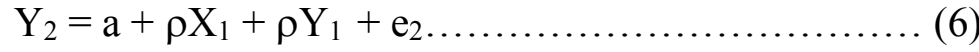

\begin{tabular}{|c|c|c|c|c|c|c|}
\hline & Model & $\begin{array}{r}\text { Sum of } \\
\text { Squares }\end{array}$ & Df & $\begin{array}{r}\text { Mean } \\
\text { Square }\end{array}$ & $\mathbf{F}$ & Sig. \\
\hline \multirow[t]{3}{*}{1} & Regression & 832,177 & 1 & 832,177 & 12,289 &, $001^{\mathrm{a}}$ \\
\hline & Residual & 5146,520 & 76 & 67,717 & & \\
\hline & Total & 5978,697 & 77 & & & \\
\hline
\end{tabular}

$$
\begin{aligned}
& \mathrm{Y}_{2}=1,120+0,090 \mathrm{X}_{1}+0,504 \mathrm{Y}_{1}+0,296 \mathrm{e}_{2} \\
& \mathrm{e}_{2}=\sqrt{1-\mathrm{R}^{2}} \\
& =\sqrt{1-0,296}=0,839
\end{aligned}
$$

Tabel 10.

Koefisien Regresi Model Pertama

Sumber: Data diolah, 2018 
Berdasarkan Tabel 10. menunjukkan hasil output SPSS, dimana hasil Uji F yang dilakukan menunjukkan nilai $\mathrm{F}$ sebesar 12,289 dengan tingkat signifikansi $0,001<0,05$ (tingkat signifikansi yang digunakan). Hal tersebut menunjukkan bahwa TAG berpengaruh secara simultan dan signifikan terhadap DER.

Tabel 11.

Koefisien Regresi Model Kedua

\begin{tabular}{rrrrrrr}
\hline & & Sum of & \multicolumn{3}{c}{ Mean } & S \\
\hline \multirow{2}{*}{1} & Squares & Df & Square & F \\
& Regression & 104,966 & 2 & 52,483 & 15,745 & \\
& Residual & 249,944 & 75 & 3,333 & & \\
& Total & 354,960 & 77 & & & \\
\hline
\end{tabular}

Sumber: Data diolah, 2018

Berdasarkan Tabel 11. menunjukkan hasil output SPSS, dimana hasil Uji F yang dilakukan menunjukkan nilai $\mathrm{F}$ sebesar 15,745 dengan tingkat signifikansi $0,000<0,05$ (tingkat signifikansi yang digunakan). Hal tersebut menunjukkan bahwa TAG, dan DER berpengaruh secara simultan dan tidak signifikan terhadap PBV.

Tabel 12.

Koefisien Regresi Model Pertama

\begin{tabular}{|c|c|c|c|c|c|c|}
\hline & \multirow[b]{2}{*}{ Model } & \multicolumn{2}{|c|}{$\begin{array}{c}\text { Unstandardized } \\
\text { Coefificients }\end{array}$} & \multirow{2}{*}{$\begin{array}{c}\text { Standardized } \\
\text { Coefficients } \\
\text { Beta }\end{array}$} & \multirow[b]{2}{*}{$\mathbf{T}$} & \multirow[b]{2}{*}{ Sig. } \\
\hline & & B & Std.Error & & & \\
\hline \multirow[t]{2}{*}{1} & (Constant) & 10,366 & 1,365 & & 7,592 &, 000 \\
\hline & $T A G \%$ &, 405 &, 115 & ,373 & 3,506 &, 001 \\
\hline
\end{tabular}

Sumber: Data diolah, 2018

Pengaruh Total asset growth $\left(\mathrm{X}_{1}\right)$ terhadap Debt to equity ratio $\left(\mathrm{Y}_{1}\right)$ pada Perusahaan Industri Barang Konsumsi yang terdaftar di BEI periode 2014-2016.

Pada Tabel 10 bisa dilihat bahwa nilai signifikansinya sebesar 0,001 lebih kecil dari 0,05 , maka $\mathrm{H}_{3}$ diterima. Hal ini menunjukkan bahwa terdapat pengaruh yang signifikan antara TAG terhadap DER pada Perusahaan Industri Barang Konsumsi yang terdaftar di BEI. Pada Standardized Coefficients menunjukkan nilai beta sebesar 0,373 yang menunjukkan arah yang positif, nilai tersebut meunjukkan bahwa jika TAG meningkat maka DER akan mengalami peningkatan juga dan sebaliknya.

Tabel 13.

Koefisien Regresi Model Kedua

\begin{tabular}{ccccccc}
\hline \multicolumn{7}{c}{ Unstandardized } \\
Coefificients & \multicolumn{2}{c}{$\begin{array}{c}\text { Standardized } \\
\text { Coefficients }\end{array}$} \\
& Model & B & Std.Error & Beta & T & Sig. \\
\hline 1 & (Constant) & 1,120 &, 402 & & 2,789 &, 007 \\
& TAG $\%$ & $q, 024$ &, 028 &, 090 &, 861 &, 392 \\
& DER $\%$ &, 123 &, 025 &, 504 & 4,823 &, 000 \\
\hline
\end{tabular}

Sumber: Data diolah, 2018

Pengaruh Total asset growth $\left(\mathrm{X}_{1}\right)$ terhadap Price book to value $\left(\mathrm{Y}_{2}\right)$ pada Perusahaan Industri Barang Konsumsi yang terdaftar di BEI periode 2014-2016. 
Pada Tabel 13. bisa dilihat bahwa nilai signifikansinya sebesar 0,392 lebih besar dari 0,05 , maka $\mathrm{H}_{1}$ diterima. Hal ini menunjukkan bahwa terdapat pengaruh yang signifikan antara TAG terhadap PBV pada Perusahaan Industri Barang Konsumsi yang terdaftar di BEI. Pada Standardized Coefficients menunjukkan nilai beta sebesar 0,090 yang menunjukkan arah yang positif, nilai tersebut menujukkan bahwa ketika TAG meningkat maka akan diikuti oleh PBV yang akan mengalami peningkatan juga dan sebaliknya.

Pengaruh Debt to equity ratio $\left(\mathrm{Y}_{1}\right)$ terhadap Price book to value $\left(\mathrm{Y}_{2}\right)$ pada Perusahaan Industri Barang Konsumsi yang terdaftar di BEI periode 2014-2016.

Pada Tabel 13. bisa dilihat bahwa nilai signifikansinya sebesar 0,000 lebih besar dari 0,05 , maka $\mathrm{H}_{2}$ ditolak. Hal ini menunjukkan bahwa terdapat pengaruh yang tidak signifikan antara DER terhadap PBV pada Perusahaan Industri Barang Konsumsi yang terdaftar di BEI. Pada Standardized Coefficients menunjukkan nilai beta sebesar 0,504 yang menunjukkan arah yang positif, nilai tersebut menujukkan bahwa ketika DER meningkat maka akan diikuti oleh PBV yang akan mengalami peningkatan juga dan sebaliknya.

Dalam penelitian ini indikator-indikator validitas model yang digunakan adalah koefisien determinasi total. Dengan rumus :

$\mathrm{R}^{2} \mathrm{~m}=1-\left(\mathrm{e}_{1}^{2}\right) \times\left(\mathrm{e}_{2}^{2}\right)$

$\mathrm{R}^{2} \mathrm{~m}=1-(0,927)^{2} \times(0,839)^{2}$

$\mathrm{R}^{2} \mathrm{~m}=0,395$

Berdasarkan perhitungan diatas menunjukkan bahwa variasi data yang dipengaruhi oleh model sebesar 3,95\%, artinya informasi yang terkadung di dalam data sebesar 3,95\% dapat dijelaskan oleh model dan sisanya sebesar 96,05\% dijelaskan oleh variabel lain di luar model.

Tabel 14.

Pengaruh Langsung, Pengaruh Tidak Langsung dan Pengaruh Total Variabel

\begin{tabular}{crll}
\hline $\begin{array}{c}\text { Pengaruh } \\
\text { Variabel }\end{array}$ & $\begin{array}{r}\text { Pengaruh } \\
\text { Langsung }\end{array}$ & \multicolumn{1}{c}{ Pengaruh Tidak Langsung } & \multicolumn{1}{c}{ Pengaruh Total } \\
\hline TAG $\rightarrow$ DER & 0,373 & - & - \\
TAG $\rightarrow$ PBV & 0,090 & $(0,373) \times(0,0504)$ & $0,090+(0,187)$ \\
& & $=0,187$ & $=0,277$ \\
DER $\rightarrow$ PBV & 0,504 & - & - \\
Sumber: Data diolah, 2018 & &
\end{tabular}

Berdasarkan Tabel 14. menunjukkan adanya pengaruh tidak langsung antara variabel Pertumbuhan Perusahaan (TAG) terhadap variabel Nilai Perusahaan (PBV) melalui variabel Struktur Modal (DER) adalah sebesar 0,187. Pengaruh langsung variabel Pertumbuhan Perusahaan (TAG) terhadap variabel Nilai Perusahaan (PBV) adalah sebesar 0,090. Hal tersebut menunjukkan bahwa struktur modal dapat mempengaruhi pertumbuhan perusahaan terhadap Nilai Perusahaan karena $0,187>0,090$.

Hasil penelitian ini menunjukkan bahwa pertumbuhan perusahaan berpengaruh positif dan signifikan terhadap nilai perusahaan pada Perusahaan 
Industri Barang Konsumsi di Bursa Efek Indonesia periode 2014-2016. Hasil penelitian tersebut mendukung hipotesis pertama yang menyatakan pertumbuhan perusahaan berpengaruh positif dan signifikan terhadap nilai perusahaan. Arah positif menunjukkan apabila pertumbuhan aset meningkat maka nilai perusahaan juga akan meningkat. Pertumbuhan suatu perusahaan merupakan tanda perusahaan memiliki aspek yang menguntungkan, dan investor pun akan mengharapkan tingkat pengembalian (rate of return) dari investasi yang dilakukan menunjukkan perkembangan yang baik dilihat dari sudut pandang investor. Hasil penelitian ini sesuai dengan hasil penelitian yang dilakukan oleh (Kusumajaya, 2011) yang menemukan bahwa pertumbuhan perusahaan berpengaruh positif dan signifikan terhadap nilai perusahaan.

Hasil penelitian ini menunjukkan bahwa struktur modal berpengaruh positif dan tidak signifikan terhadap nilai perusahaan pada Perusahaan Industri Barang Konsumsi di Bursa Efek Indonesia periode 2014-2016. Hasil penelitian tersebut tidak mendukung hipotesis kedua yang menyatakan struktur modal berpengaruh positif dan signifikan terhadap nilai perusahaan. Arah positif menunjukkan apabila struktur modal meningkat maka akan diikuti dengan nilai perusahaan yang mengalami peningkatan. Menurut teori trade-off, dalam kaitan penggunaan hutang optimal untuk meningkatkan nilai perusahaan dalam penelitian ini mungkin belum optimal. Ini mengindikasikan nilai perusahaan yang lebih besar dibandingkan hutang pada sebuah perusahaan belum bisa menunjukkan kemampuan perusahaan dalam mengoptimalkan penggunakan hutang untuk peningkatan nilai perusahaan, karena dalam pasar modal Indonesia pergerakan harga saham dan penciptaan nilai tambah perusahaan disebabkan keadaan pasar. Besar kecilnya hutang yang dimiliki perusahaan tidak terlalu diperhatikan oleh investor, karena investor lebih melihat bagaimana pihak manajemen perusahaan mengunakan dana tersebut dengan efektif dan efisien untuk mencapai nilai tambah bagi nilai perusahaan. Hasil ini konsisten dengan penelitian (Ogolmagai, 2013) dan (Kayobi \& Anggreani, 2015) yang menyatakan bahwa Debt to Equity Ratio (DER) pengaruh positif dan tidak signifikan terhadap nilai perusahaan.

Hasil penelitian ini menunjukkan bahwa pertumbuhan perusahaan berpengaruh positif dan tidak signifikan terhadap struktur modal pada Perusahaan Industri Barang Konsumsi di Bursa Efek Indonesia periode 2014-2016. Hasil penelitian tersebut mendukung hipotesis ketiga yang menyatakan pertumbuhan perusahaan berpengaruh positif dan tidak signifikan terhadap struktur modal. Arah positif menunjukkan bahwa ketika pertumbuhan perusahaan mengalami peningkatan maka struktur modal juga akan mengalami peningkatan, dimana pertumbuhan perusahaan yang mengalami peningkatan tersebut terjadi karena ukuran perusahaan, apabila perusahaan yang memiliki ukuran yang luas tentu akan memerlukan pendanaan yang berasal dari dalam maupun dari luar perusahaan dan akan meningkatkan struktur modal dari perusahaan tersebut.

Hasil penelitian ini sesuai dengan hasil penelitian yang sudah dilakukan oleh (Manulang, 2011) yang menemukan bahwa pertumbuhan perusahaan dan struktur modal memiliki pengaruh yang positif dan signifikan. Tingkat pertumbuhan perusahaan menunjukkan seberapa besar perusahaan dalam menggunakan hutang sebagai sumber pembiayaan. Perusahaan yang memiliki tingkat pertumbuhan yang 
tinggi akan cenderung menghasilkan arus kas yang lebih besar sehingga perusahaan akan lebih mengandalkan pendanaan internal. Dalam hubungannya dengan struktur modal, perusahaan dengan tingkat pertumbuhan yang tinggi sebaiknya menggunakan ekuitas sebagai sumber pembiayaannya agar tidak terjadi keagenan antara pemegang saham dengan manajemen perusahaan. Sebaliknya, perusahaan dengan tingkat pertumbuhan yang rendah lebih baik menggunakan hutang sebagai sumber pembiayaannya karena pembayaran hutang akan mengharuskan perusahaan tersebut membayar bunga secara teratur (Dwilestari, 2010).

Pengujian hipotesis pada peran struktur modal dalam memediasi pengaruh pertumbuhan perusahaan terhadap nilai perusahaan mendapatkan hasil bahwa struktur modal (DER) mampu memediasi pengaruh pertumbuhan perusahaan terhadap nilai perusahaan. Dapat dilihat dari pengaruh tidak langsung pertumbuhan perusahaan (TAG) terhadap variabel nilai perusahaan (PBV) melalui struktur modal (DER) adalah sebesar 0,817, sedangkan pengaruh langsung variabel pertumbuhan perusahaan adalah sebesar 0,090 . Hal tersebut menunjukkan bahwa struktur modal dapat mempengaruhi pertumbuhan perusahaan terhadap nilai perusahaan karena $0,187>0,090$.

Perusahaann yang memiliki pertumbuhan total aset yang besar mencerminkan perusahaan tersebut mampu menghasilkan laba yang bisa dimanfaatkan untuk penambahan jumlah asset yang kemudian dapat meningkatkan nilai perusahaan. Struktur modal didalam perusahaan sangat berperan penting karena apabila perusahaan menggunakan modal sebaik-baiknya maka akan meningkatkan nilai dari perusahaan.

Pertumbuhan perusahaan berpengaruh positif dan signifikan terhadap nilai perusahaan. Pertumbuhan adalah dampak atas arus dana perusahaan dari perubahan operasional yang disebabkan oleh pertumbuhan atau penurunan volume usaha. Pertumbuhan perusahaan sangat diharapkan oleh pihak internal maupun eksternal perusahaan, karena pertumbuhan yang baik memberi tanda bagi perkembangan perusahaan. Dari sudut pandang investor, pertumbuhan suatu perusahaan merupakan tanda perusahaan memiliki aspek yang menguntungkan, dan investor pun akan mengharapkan tingkat pengembalian (rate of return) dari investasi yang dilakukan menunjukkan perkembangan yang baik. Hasil temuan ini membuktikan bahwa pengaruh pertumbuhan perusahaan terhadap nilai perusahaan berpengaruh positif dan signifikan.

Struktur modal berpengaruh positif dan tidak signifikan terhadap nilai perusahaan. Teori trade-off, dalam kaitan penggunaan hutang optimal untuk meningkatkan nilai perusahaan dalam penelitian ini mungkin belum optimal. Ini mengindikasikan nilai perusahaan yang lebih besar dibandingkan hutang pada sebuah perusahaan belum bisa menunjukkan kemampuan perusahaan dalam mengoptimalkan penggunakan hutang untuk peningkatan nilai perusahaan, karena dalam pasar modal Indonesia pergerakan harga saham dan penciptaan nilai tambah perusahaan disebabkan Keadaan pasar. Besar kecilnya hutang yang dimiliki perusahaan tidak terlalu diperhatikan oleh investor, karena investor lebih melihat bagaimana pihak manajemen perusahaan mengunakan dana tersebut dengan efektif dan efisien untuk mencapai nilai tambah bagi nilai perusahaan. Struktur modal adalah skala antara penggunaan pinjaman hutang jangka panjang dengan 
penggunaan modal sendiri, artinya adalah seberapa besar modal sendiri dan seberapa besar hutang jangka panjang yang akan dipakai sehingga dapat optimal. Dengan digunakannya struktur modal yang optimal maka perusahaan yang mempunyai struktur modal optimal akan menghasilkan tingkat pengembalian yang optimal juga sehingga bukan hanya perusahaan yang memperoleh keuntungan, tetapi para pemegang saham pun ikut memperoleh keuntungan tersebut.

Pertumbuhan perusahaan berpengaruh positif dan signifikan terhadap struktur modal. Pertumbuhan perusahaan memerlukan modal di luar cadangan internal perusahaan yang di gunakan untuk membiayai investasi, maka dari itu struktur permodalan sebuah perusahaan sangat penting karena berkaitan dengan kemampuan perusahaan untuk memenuhi kebutuhan investor. Menurut teori trade off, apabila perusahaan dengan peluang pertumbuhan yang tinggi akan memiliki pendapatan yang lebih tinggi, sehingga perusahaan akan menerbitkan lebih banyak hutang untuk mempertahankan rasio hutang maka perusahaan cenderung memiliki struktur modal yang lebih tinggi. Di sisi lain peningkatan proporsi utang yang lebih besar daripada modal sendiri menunjukkan debt to total assets ratio semakin besar. Dengan demikian pertumbuhan aset diprediksi berpengaruh positif terhadap struktur modal yang berarti semakin besar tingkat pertumbuhan aset perusahaan, maka semakin besar pula tingkat utang per nilai asetnya.

Struktur modal mampu memediasi pengaruh pertumbuhan perusahaan terhadap nilai perusahaan. Perusahaan yang memiliki total aktiva yang besar mencerminkan perusahaan tersebut mampu menghasilkan laba yang dapat dimanfaatkan untuk penambahan jumlah aktiva yang kemudian dapat meningkat nilai perusahaan. Perusahaan yang memiliki struktur modal yang lebih besar dibandingkan hutang akan lebih mudah untuk mengembangkan perusahaan dan meningkatkan profit perusahaan sehingga meningkatkan persepsi investor terhadap perusahaan. Peningkatan persepsi investor terhadap perusahaan juga akan membuat pertumbuhan perusahaan meningkat, pembayaran dividen kepada investor juga meningkat yang kemudian akan memberikan dampak positif terhadap nilai perusahaan.

\section{SIMPULAN}

Pertumbuhan perusahaan berpengaruh positif dan tidak signifikan terhadap nilai perusahaan pada Perusahaan Industri Barang Konsumsi di BEI periode 20142016. Hal tersebut menunjukkan bahwa ketika perusahaan memiliki pertumbuhan total aktiva yang tinggi maka akan lebih mudah untuk mendapatkan perhatian dari pihak investor dan kreditor karena dapat mencerminkan perusahaan tersebut mampu untuk menghasilkan laba yang dimanfaatkan untuk menambah jumlah aktiva yang kemudian dapat digunakan untuk meningkatkan nilai perusahaan. Struktrur modal berpengaruh positif dan signifikan terhadap nilai perusahaan pada Perusahaan Industri Barang Konsumsi di BEI periode 2014-2016. Hal tersebut menunjukkan bahwa perusahaan dengan hutang tinggi dapat memiliki nilai perusahaan yang tinggi, apabila hutang dikelola dengan baik sehingga perusahaan memiliki market value equity besar. Begitu pula jika perusahaan memiliki tingkat hutang rendah juga dapat memiliki nilai perusahaan yang tinggi, apabila nilai 
market value equity perusahaan besar. Sehingga besar kecilnya hutang perusahaan berpengaruh tidak signifikan terhadap nilai perusahaan.

Pertumbuhan perusahaan berpengaruh positif dan signifikan terhadap struktur modal pada pada Perusahaan Industri Barang Konsumsi di BEI periode 2014-2016. Hal tersebut menunjukkan ketika terjadi peningkatan proporsi utang yang lebih besar daripada modal sendiri menunjukkan debt to total assets ratio nya semakin besar. Dengan demikian pertumbuhan aset diprediksi berpengaruh positif terhadap struktur modal yang berarti semakin besar tingkat pertumbuhan aset perusahaan, maka semakin besar pula tingkat utang per nilai asetnya. Struktur modal mampu memediasi pengaruh pertumbuhan perusahaan terhadap nilai perusahaan pada pada Perusahaan Industri Barang Konsumsi di BEI periode 2014-2016. Hasil tersebut menunjukkan bahwa perusahaan yang memiliki struktur modal yang lebih besar dengan di bandingkan hutang akan lebih mudah untuk mengembangkan perusahaan dan meningkatkan profit perusahaan sehingga meningkatkan persepsi investor terhadap perusahaan. Peningkatan persepsi investor terhadap perusahaan akan berdampak pada pertumbuhan perusahaan dimana akan membuat pertumbuhan perusahaan meningkat, pembayaran dividen kepada investor juga meningkat yang akan memberikan dampak positif terhadap nilai perusahaan.

Bagi peneliti selanjutnya dapat mengembangkan hasil penelitian dengan menggunakan variabel lain yang dapat mempengaruhi nilai perusahaan dan dapat menggunakan objek perusahaan lain sebagai tempat melakukan penelitian, menambah periode penelitian yang lebih lama, serta dapat menggunakan teknik analisis data yang berbeda.

Bagi pihak manajemen perusahaan Industri Barang Konsumsi yang terdaftar di BEI di sarankan agar lebih memperhatikan lagi pertumbuhan perusahaan, penggunaan struktur modal (perimbangan penggunaan hutang dan modal sendiri), sehingga perusahaan mampu untuk meningkatkan kinerjanya serta memberikan persepsi bagi calon investor.

\section{REFERENSI}

Akinyomi, O. J., \& Olagunju, A. (2013). Determinants of Capital Structure in Nigeria. International Journal of Innovation and Applied Studies, 3(4), 9991005. https://doi.org/10.1016/j.sbspro.2014.07.558

Antwi, S., Mills, E. F. E. A., \& Zhao, P. X. (2012). Capital Structure and Firm Value: Empirical Evidence from Ghana. International Journal Od Business and Social Science, 3(22), 103-111. Retrieved from http://cpanel.petra.ac.id/ejournal/index.php/aku/article/viewArticle/17083

Brigham, E. F., \& Houston, J. F. (2011). Dasar-Dasar Manajemen Keuangan (10th ed.). Jakarta: Salemba Empat.

Chen, S. Y., \& Chen, L. J. (2011). Capital Structure Determinants: An Empirical Study in Taiwan. African Journal of Business Management, 5(27), 1097210983. https://doi.org/10.5897/ajbm10.1334 
Daskalakis, N., Eriotis, N., Thanou, E., \& Vasiliou, D. (2014). Capital Structure and Size: New Evidence Across the Broad Spectrum of SMES. Managerial Finance, 40(12), 1207-1222. https://doi.org/10.1108/MF-11-2013-0325

Dewi, D. A. I. Y. M., \& Sudiartha, G. M. (2017). Pengaruh Profitabilitas, Ukuran Perusahaan, Dan Pertumbuhan Aset Terhadap Struktur Modal Dan Nilai Perusahaan. E-Jurnal Manajemen Unud, 6(4), 2222-2252.

Dhani, I. P., \& Utama, A. A. G. S. (2017). Pengaruh Pertumbuhan Perusahaan, Struktur Modal, dan Profitabilitas Terhadap Nilai Perusahaan. Jurnal Riset Akuntansi Dan Bisnis Airlangga, 2(1), 135-148.

Dwilestari, A. (2010). Pengaruh Struktur Aktiva, Pertumbuhan, dan Likuiditas Terhadap Struktur Modal Perusahaan. Jurnal Riset Akuntansi Dan Keuangan, 6(2), 153-165.

Fau, N. R. (2015). Pengaruh Struktur Modal, Pertumbuhan Perusahaan, Ukuran Perusahaan dan Profitabilitas Terhadap Nilai Perusahaan Pada Perusahaan Manufaktur yang Terdaftar di Bursa Efek Indonesia.

Hermuningsih, S. (2013). Pengaruh Profitabilitas, Growth Opportunity, Struktur Modal Terhadap Nilai Perusahaan Pada Perusahaan Publik di Indonesia. In Bulletin Ekonomi Moneter dan Perbankan (Vol. 18). https://doi.org/10.1177/027046769801800106

Hoque, J., Hossain, A., \& Hossain, K. (2014). Impact of Capital Structure Policy on Value of the Firm - A Study on Some Selected Corporate Manufacturing Firms Under Dhaka Stock Exchange. Journal Ecoforum, 3(2), 77-84.

Husnan, S., \& Pudjiastuti, E. (2012). Dasar-Dasar Manajemen Keuangan (Keenam). Yogyakarta: UPP STIM YKPN.

Kartika, A. (2016). Pengaruh Profitabilitas, Struktur Aset, Pertumbuhan Penjualan dan Ukuran Perusahaan Terhadap Struktur Modal Perusahaan Manufaktur di Bursa Efek Indonesia. Jurnal AMIK JTC $\backslash$ INFOKAM, 12(1), 49-58. Retrieved from http://amikjtc.com/jurnal/index.php/jurnal/article/view/99

Kayobi, I. G. M. A., \& Anggreani, D. (2015). Pengaruh Debt to Equity Ratio (DER), Debt to Total Asset (DTA), DIviden Tunai, dan Ukuran Perusahaan Terhadap Nilai Perusahaan (Perusahaan Manufaktur Sektor Barang Konsumsi yang Terdaftar di Bursa Efek Indonesia Periode 2011-2014). Jurnal Akuntansi Keuangan, 4(1), 100-120.

Kusumajaya, D. K. O. (2011). Pengaruh Struktur Modal dan Pertumbuhan Perusahaan terhadap Profitabilitas dan Nilai Perusahaan pada Perusahaan Manufaktur di Bursa Efek Indonesia. 
Manulang, M. (2011). Manajemen Personalia. Jakarta: Aksara Baru.

Meidiawati, K., \& Mildawati, T. (2016). Pengaruh Size, Growth, Profitabilitas, Struktur Modal, Kebijakan Dividen Terhadap Nilai Perusahaan. Jurnal Ilmu Dan Riset Akuntansi, 5(2), 1-16.

Ogolmagai, N. (2013). Levereage Pengaruhnya Terhadap Nilai Perusahaan Pada Industri Manufaktur Yang Go Public di Indonesia. Jurnal EMBA, 1(3), 81-89.

Parta, K. A. C. P. P., \& Sedana, I. B. P. (2018). Peran Struktur Modal Dalam Memediasi Pengaruh Pertumbuhan Perusahaan Terhadap Nilai Perusahaan Pada Perusahaan Properti di BEI. E-Jurnal Manajemen Unud, 7(5), 26802709. https://doi.org/10.24843/EJMUNUD.2018.v7.i05.p15 ISSN

Purwohandoko. (2017). The Influence of Firm's Size, Growth, and Profitability on Firm Value with Capital Structure as the Mediator: A Study on the Agricultural Firms Listed in the Indonesian Stock Exchange. International Journal of Economics and Finance, 9(8), 103-110. https://doi.org/10.5539/ijef.v9n8p103

Rehman, O. u. (2016). Impact of Capital Structure and Dividend Policy on Firm Value. Journal of Poverty, Investment and Development, 21, 40-57. Retrieved from www.iiste.org

Riaz, M., \& Qasim, M. (2016). Islamic Microfinance Institution: the Capital Structure, Growth, Perfomance and Value of the Firm in Pakistan. Journal of ISOSS, 2(1), 97-101.

Sari, P. I. . P., \& Abundanti, N. (2014). Pengaruh Pertumbuhan Perusahaan dan Levereage Terhadap Profitabilitas dan Nilai Perusahaan. E-Jurnal Manajemen Unud, 3(5), 1427-1441.

Sartono, A. (2014). Manajemen Keuangan Teori dan Aplikasi (Empat). Yogyakarta: BPFE.

Sudiani, N. K. A., \& Darmayanti, N. P. A. (2016). Pengaruh Profitabilitas,Likuiditas,Pertumbuhan dan Investment Opportunity Set Terhadap Nilai Perusahaan. E-Jurnal Manajemen Unud, 5(7), 4545-4547.

Susanto, E. (2016). Pengaruh Profitabilitas, Kepemilikan Manajerial, dan Pertumbuhan Perusahaan (Growth) Terhadap Struktur Modal dan Nilai Perusahaan. Jurnal STIE Semarang, 8(3), 1-20.

Wiagustini, N. L. P. (2013). Manajemen Keuangan. Denpasar: Udayana University Press. 